\title{
HUBUNGAN PENGETAHUAN PENGASUH TENTANG POSISI PEMBERIAN MAKAN DENGAN ASUPAN ENERGI DAN PROTEIN ANAK CEREBRAL PALSY DI YPAC MALANG
}

\author{
Fajar Ari Nugroho ${ }^{\star 凶}$, Median Rolando*, Olivia Anggraeny*
}

\begin{abstract}
Abstrak
Anak cerebral palsy memiliki masalah kesulitan makan yang menyebabkan asupan zat gizinya kurang, sehingga peran pengasuh sangatlah penting. Posisi pemberian makan adalah salah satu cara untuk mengatasi masalah makan pada anak cerebral palsy. Penelitian ini bertujuan untuk mengetahui hubungan pengetahuan pengasuh tentang posisi pemberian makan dengan asupan energi dan protein pada anak cerebral palsy di Yayasan Pembinaan Anak Cacat (YPAC) Malang. Desain penelitian ini adalah cross sectional study. Subjek (12 pengasuh) dipilih dengan cara total sampling sesuai kriteria inklusi. Hasil penelitian ini menunjukkan bahwa $66,7 \%$ tingkat pengetahuan pengasuh tentang posisi pemberian makan tergolong baik. Rerata asupan energi dan protein anak lebih rendah dibandingkan dengan angka kecukupan gizi. Sejumlah $75 \%$ anak cerebral palsy memiliki asupan energi defisit ( $42 \%$ asupan defisit berat dan 33\% defisit ringan). Sementara itu, 50\% anak memiliki asupan protein defisit (33\% asupan defisit berat dan 17\% asupan defisit ringan). Uji korelasi Pearson menunjukkan tidak terdapat hubungan antara pengetahuan pengasuh tentang posisi pemberian makan dengan asupan energi maupun dengan asupan protein (masing-masing, $p=0,994$ dan $p=0,526$ ). Kesimpulan dari penelitian ini menunjukkan tidak adanya hubungan antara pengetahuan pengasuh tentang posisi pemberian makan dengan asupan gizi anak cerebral palsy.
\end{abstract}

Kata kunci: cerebral palsy, energi, makan, posisi, protein.

\section{RELATIONSHIP BETWEEN CAREGIVER KNOWLEDGE ON FEEDING POSITION AND NUTRITION INTAKE IN CEREBRAL PALSY CHILDREN AT YPAC MALANG}

\begin{abstract}
Cerebral palsy children have eating problem that cause in low nutrient intake. So, the caregiver role is very important to prevent eating problems. Feeding position is one of techniques, which is a solving for eating problem in cerebral palsy. This study was aimed to explain about relationship between feeding position knowledge of caregiver and nutrition intake in cerebral palsy children at YPAC Malang. The study design was cross-sectional study. Subjects (12 caregivers) were selected by total sampling method based on the inclusion criterias. The results showed $66.7 \%$ of the caregiver level of knowledge were good. The mean of energy and protein intake were lower than dietary reference intakes (DRI). Energy intake was $75 \%$ classified as deficit ( $42 \%$ severe deficit and $33 \%$ mild deficit). Furthermore, the percentage of protein intake was classified as deficit by $50 \%$ (33\% severe deficit and $17 \%$ mild deficit). Pearson correlation test showed there was no association between caregiver's feeding position knowledge with energy intake, and also with protein intake $(p=0.994$ and $p=0.526$, respectively). In conclusion, there is no relationship between caregiver's knowledge on feeding position with nutrition intake in cerebral palsy children.
\end{abstract}

Keywords: cerebral palsy, position, feeding, energy, protein

* Program Studi llmu Gizi, FKUB

区e-mail : fanmerah@gmail.com 


\section{Pendahuluan}

Masalah makan terjadi pada $25 \%$ anak normal dan $80 \%$ pada anak dengan gangguan perkembangan terutama cerebal palsy. ${ }^{1}$ Cerebral palsy merupakan sindrom kerusakan motorik nonprogresif akibat kelainan perkembangan otak yang timbul sebelum atau setelah lahir. Kelainan ini menyebabkan kemampuan sensorik dan motorik menjadi lemah, kemampuan belajar berkurang, gangguan perilaku, serta kejang.,2,3 Masalah yang dialami anak cerebral palsy sangatlah kompleks akibat dari kecacatannya seperti masalah kecacatan fisik, gangguan mental, sosial, keterampilan, dan pendidikannya. ${ }^{4}$

Pengetahuan tentang masalah makan sangatlah penting untuk membantu perkembangan dan pertumbuhan anak cerebral palsy. Masalah makan mempengaruhi jumlah asupan gizi anak cerebral palsy. Penelitian yang dilakukan di YPAC Semarang menyebutkan bahwa rerata asupan kalori $(81,5 \%)$ dan protein $(33,3 \%)$ pada anak cerebral palsy $(n=27)$ lebih rendah dari kebutuhan kalori dan protein individu. ${ }^{1}$ Asupan energi dan protein di bawah standar Angka Kecukupan Gizi (AKG) yaitu 77\% dapat menyebabkan anak mengalami status gizi kurang. Status gizi kurang dapat mempengaruhi kondisi anak. ${ }^{5,6}$

Pemberian makan pada anak cerebral palsy sangatlah tergantung pada pengasuh. ${ }^{7}$ Pengetahuan pengasuh yang baik dapat mempengaruhi perubahan sikap dalam pemberian makan sehingga berhubungan dengan pemenuhan nutirisi dan kesehatan anak. ${ }^{8,9}$ Pengetahuan adalah kunci utama terjalinnya hubungan pemberian makan antara pengasuh dengan anak cerebral palsy. ${ }^{7}$

Ada beberapa aspek yang harus dipelajari oleh pengasuh yaitu keterampilan makan (posisi pemberian dan alat bantu makan), proses menelan, asupan makanan, pengetahuan dan sikap keluarga/pengasuh pada waktu makan. Pengetahuan pengasuh yang baik tentang masalah kesulitan makan dan posisi pemberian makan yang benar diharapkan bisa memenuhi asupan gizi anak cerebral palsy. 5,10
Penelitian ini bertujuan untuk mengetahui ada tidaknya hubungan pengetahuan pengasuh tentang posisi pemberian makan dengan asupan energi dan protein anak cerebral palsy di Yayasan Pembinaan Anak Cacat (YPAC) Malang.

Manfaat penelitian ini yaitu memberikan informasi posisi pemberian makan sebagai upaya peningkatan asupan anak cerebral palsy.

\section{Bahan dan Metode}

Desain penelitian ini adalah deskriptif analitik dengan pendekatan cross sectional, dengan teknik pengambilan sampel menggunakan total sampling berdasarkan kriteria inklusi.

Populasi anak cerebral palsy yang ditemukan pada saat penelitian berjumlah 20 anak dengan tingkat keparahan sedang hingga berat. Sejumlah 10 anak tinggal di asrama dan sisanya tinggal bersama orang tua masingmasing. Para pengasuh anak dipilih berdasarkan kriteria inkusi yaitu belum pernah mendapatkan pelatihan tentang posisi makan anak dengan cerebral palsy, bertanggung jawab atas pemberian makan pada anak, dan anak cerebral palsy yang diasuh tidak berumur antara 6-16 tahun. Jika pengasuh diketahui telah memperoleh pelatihan posisi makan maka akan dikeluarkan dari penelitian.

Pengetahuan pengasuh diukur dengan menggunkan kuisioner pengetahuan posisi pemberian makan pada anak cerebral palsy meliputi posisi duduk, kepala, tangan dan kaki pada anak yang telah digunakan dalam penelitian Hambisella. Sementara itu, data mengenai asupan makan diketahui melalui form recall konsumsi selama 3 hari yang telah digunakan pada penelitian Sugiarto. ${ }^{1}$ Pengukuran tinggi badan atau tinggi lutut dan berat badan dilakukan untuk mengetahui ukuran antropometri anak.

Analisis data dilakukan dengan uji korelasi Pearson. Hasil pengujian ini kemudian digunakan untuk memaknai hubungan antar variabel dalam penelitian ini. 
Hasil

Penelitian ini mengikutsertakan 12 pengasuh anak cerebral palsy yang telah memenuhi kriteia inklusi. Berdasarkan Tabel 1 dapat dilihat bahwa usia anak cerebral palsy terdapat $58 \%$ berusia 10 hingga 13 tahun. Berdasarkan Tabel 2 dapat dilihat bahwa tingkat pengetahuan pengasuh yang baik sebanyak $66,7 \%$.

Tabel 1. Usia anak cerebral palsy

\begin{tabular}{ccc}
\hline Usia (tahun) & Jumlah & Persentase $(100 \%)$ \\
\hline $10-13$ & 7 & 58,3 \\
$14-16$ & 5 & 41,7 \\
\hline Total & 12 & 100 \\
\hline
\end{tabular}

Tabel 2. Distribusi pengetahuan pengasuh tentang posisi pemberian makan

\begin{tabular}{ccc}
\hline Pengetahuan & Jumlah & Persentase (100\%) \\
\hline Baik & 8 & 66,7 \\
Kurang & 4 & 33,3 \\
\hline Total & 12 & 100
\end{tabular}

Keterangan: pengetahuan pengasuh dikategorikan menjadi sebagai baik (apabila $\geq$ median skor pengetahuan seluruh pengasuh) dan kurang (apabila <median skor pengetahuan seluruh pengasuh)

Pada Gambar 1, menunjukkan bahwa perbandingan rerata asupan energi anak adalah $1638,85 \pm 421,73$, sedangkan rerata kebutuhan energi berdasarkan AKG 2155,21 $\pm 248,7$.
Dengan demikian, dapat disimpulkan bahwa rerata asupan energi lebih rendah daripada kebutuhan energi menurut AKG.

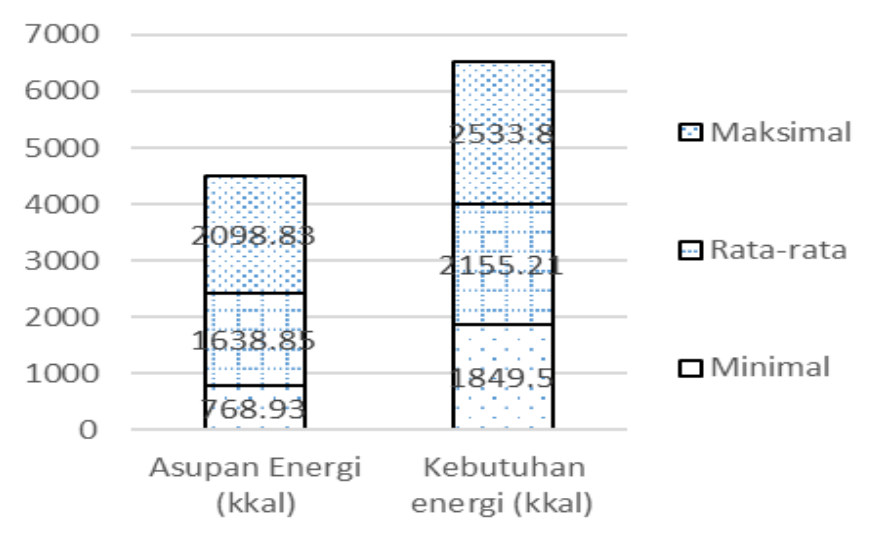

Gambar 1. Distribusi asupan energi dan kebutuhan energi.

Keterangan: kebutuhan energi berdasarkan Angka Kecukupan Gizi (AKG) tahun 2014

Pada Gambar 2, menunjukkan bahwa perbandingan rerata asupan protein anak $53,13 \pm 11,16$ dengan rerata kebutuhan protein berdasarkan AKG protein $58,97 \pm 9,2$. Jadi dapat disimpulkan bahwa rerata asupan protein lebih rendah daripada kebutuhan protein menurut AKG. 


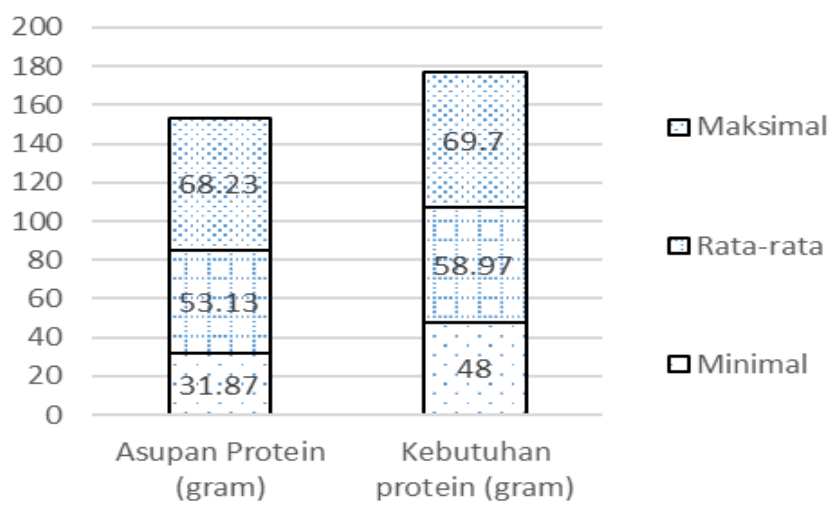

Gambar 2. Distribusi asupan protein dan kebutuhan protein

Keterangan: kebutuhan protein berdasarkan Angka Kecukupan Gizi (AKG) tahun 2014

Jika data dikelompokkan dalam klasifikasi persentase terhadap AKG maka akan diperoleh proporsi sesuai Gambar 3, yaitu bahwa persentase asupan energi termasuk dalam kategori defisit berat $(42 \%)$ dan defisit ringan
$(33 \%)$ Sementara itu, untuk protein proporsi terbesar tetap pada kelompok defisit berat $(33 \%)$ setara dengan proporsi normal $(33 \%)$ dan tidak ada asupan energi dan protein dengan kategori defisit sedang.
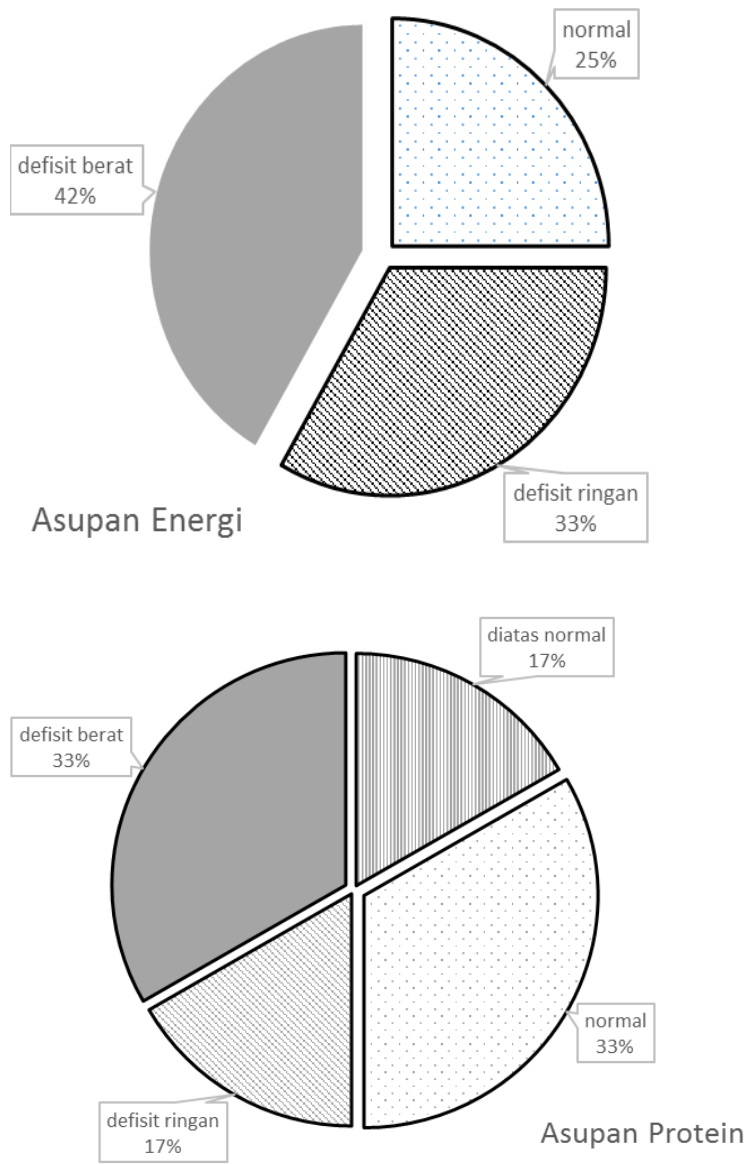

Gambar 3. Persentase kategori asupan energi dan protein menurut AKG

Analisis pengetahuan pengasuh tentang posisi pemberian makan dengan asupan energi dapat dilihat pada Gambar 4. Berdasarkan gambar tersebut, diketahui bahwa dari pengasuh yang berpengetahuan baik terdapat anak dengan asupan energi pada kategori 
defisit berat $(25 \%)$ dan defisit ringan (25\%), sedangkan dari pengasuh yang berpengetahuan kurang terdapat anak dengan asupan energi pada kategori defisit ringan $(8,3 \%)$ dan defisit berat $(16,7 \%)$. Tidak ada pengasuh yang memiliki pengetahuan baik dan kurang dengan anak dalam kategori asupan energi defisit sedang. Berdasarkan analisis uji normalitas diketahui bahwa data terdistribusi normal, maka dilakukan uji korelasi Pearson. Kemudian diperoleh hasil tidak terdapat hubungan yang signifikan antara pengetahuan pengasuh tentang posisi pemberian makan dengan asupan energi pada anak cerebral palsy dengan nilai $p$ sebesar $0,994(p>0,05)$.

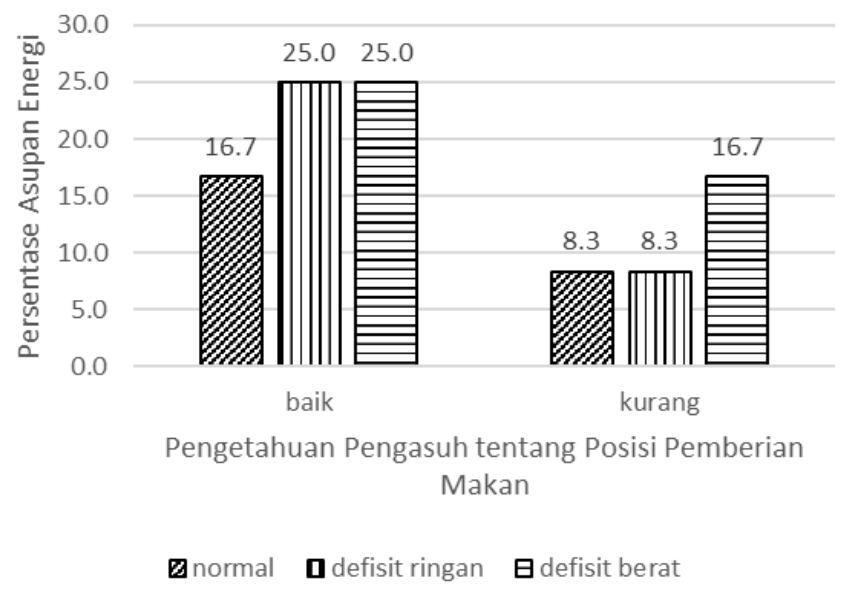

Gambar 4. Asupan energi berdasarkan pengetahuan pengasuh

Berdasarkan Gambar 5, didapatkan hasil bahwa pengasuh yang berpengetahuan baik terdapat anak dengan katagori asupan protein defisit berat $(25 \%)$ dan defisit ringan $(16,7 \%)$, sedangkan dari pengasuh yang berpengetahuan kurang terdapat anak dengan asupan protein kategori defisit berat (8,3\%). Tidak ada pengasuh yang memiliki pengetahuan baik dan kurang dengan anak dalam kategori asupan protein defisit sedang. Berdasarkan analisis uji normalitas diketahui bahwa data terdistribusi normal maka dilakukan uji korelasi Pearson. Hasil uji menunjukkan tidak terdapat hubungan yang signifikan antara pengetahuan pengasuh tentang posisi pemberian makan dengan asupan protein pada anak cerebral palsy dengan nilai $p$ sebesar $0,526(p>0,05)$.

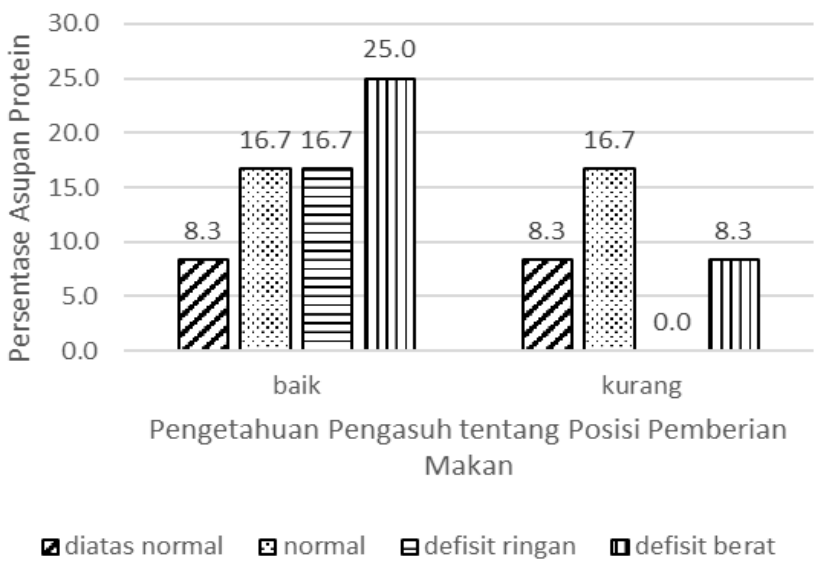

Gambar 5. Asupan protein berdasarkan pengetahuan pengasuh 


\section{Pembahasan}

\section{Pengetahuan Pengasuh tentang Posisi Pemberian Makan}

Hasil penelitian ini menunjukkan bahwa tingkat pengetahuan pengasuh tentang posisi pemberian yang baik hanya $66,7 \%$. Penelitian lain menunjukkan bahwa pengetahuan terkait posisi pemberian makan dan definisi anak cerebral palsy pada pengasuh sangat kurang pada hasil pretestnya. ${ }^{14}$

Posisi pemberian makan yang benar serta dukungan fisik dapat memberikan kenyamanan saat makan. Pengaturan posisi pemberian makan tidak hanya pada pengaturan posisi tempat duduk saja, akan tetapi posisi kepala dan tubuh juga diperlukan pengaturannya agar pemberian makan menjadi lebih mudah dan nyaman bagi anak. Pengaturan posisi tubuh yang optimal pada saat makan dapat dilakukan dengan cara mengatur posisi duduk tegak 90 derajat serta posisi kepala anak dapat disesuaikan dengan kenyamanan anak saat makan. Selain itu, juga penggunaan kursi dan fasilitas makan dapat mempengaruhi proses makan. ${ }^{12,13}$

Kurangnya pengetahuan pengasuh tentang aktivitas hidup sehari-hari anak yang salah satunya adalah pemberian makan pada anak cerebral palsyhemiplegia yang berdampak terhadap kesehatan anak. 14,15

Pengetahuan tentang posisi pemberian yang baik bagi pengasuh dapat membantu proses makan anak cerebral palsy. Jika pengasuh memiliki pengetahuan tentang posisi pemberian makan yang baik,maka akan memudahkan pengasuh dalam merawat anak dan asupan gizi anak dapat terpenuhi.

\section{Asupan Energi dan Protein}

Berdasarkan analisis penelitian didapatkan bahwa sebagian besar anak cerebral palsy memiliki asupan energi yaitu sebanyak $75 \%$ yang tergolong defisit (42\% asupan defisit berat dan 33\% defisit ringan). Sementara, persentase asupan protein yaitu sebanyak $50 \%$ tergolong defisit (33\% asupan defisit berat dan 17\% asupan defisit ringan). Sebagaimana halnya penelitian yang dilakukan di YPAC Semarang didapatkan bahwa asupan energi dan protein anak cerebral palsy lebih rendah dibandingkan dengan kebutuhan kalori dan protein. ${ }^{1}$ Penelitian ini juga sejalan dengan penelitian yang dilakukan pada 30 anak-anak cacat neuromotor berusia 2-15 tahun, rerata asupan kalori sangat rendah pada $43 \%$ pasien. Hal ini disebabkan karena ketidakseimbangan antara jumlah asupan protein, lemak, dan karbohidrat. ${ }^{16}$

Kekurangan asupan gizi pada anak dengan gangguan saraf dapat terjadi kerena faktor gizi dan non gizi. Adapun penyebab kekurangan asupan gizi dari faktor gizi adalah disfagia atau kesulitan menelan, kesulitan makan sendiri, mengunyah, menggigit, menghisap, penolakan terhadap makanan. Kesulitan menelan pada anak cerebral palsy menyebabkan makanan yang tertelan hanya sedikit sehingga proses pemberian makan menjadi lebih lama, yang dapat meningkatkan stres pengasuh. Sementara itu, faktor non gizi adalah tingkat keparahan neurologis anak, tingkat kecerdasan anak dan penggunaan obat antiepilepsi. ${ }^{1}, 17,18$

Masalah makan pada anak cerebral palsy haruslah dapat diatasi agar asupan makan pada anak cerebral palsy dapat terpenuhi sesuai kebutuhannya. Asupan gizi sangat diperlukan untuk perkembangan dan pertumbuhan anak. Jika asupan gizi kurang maka akan berdampak pada kesehatan anak terutama anak cerebral palsy yang memiliki masalah makan. Peran pengasuh sangalah penting dalam pemberian makan pada anak cerebral palsy.

\section{Hubungan Pengetahuan Pengasuh tentang Posisi Pemberian Makan dengan Asupan Energi}

Berdasarkan analisis penelitian didapatkan bahwa tidak terdapat hubungan yang signifikan antara pengetahuan pengasuh tentang posisi pemberian makan dengan asupan energi pada anak cerebral palsy di YPAC Malang dengan nilai $p$ sebesar $0,994(p>0,05)$.

Penelitian yang dilakukan di Velore didapatkan bahwa tidak ada hubungan antara pengetahuan pengasuh dengan pemilihan teknik pemberian makan pada anak cerebral palsy. Hal ini disebabkan banyak pengasuh yang tidak mengetahui teknik pemberian makan pada anak cerebral palsy. Teknik pemberian makan dipengaruhi oleh data demografik seperti usia, tingkat pendidikan dan pengalaman mengasuh anak cerebral palsy. ${ }^{19}$ Berbeda dengan 
penelitian yang dilakukan oleh Verall dkk, yang menyebutkan adanya hubungan antara pengetahuan dan sikap pengasuh terhadap nutrisi dan kesehatan anak. ${ }^{8}$

Kurangnya pengetahuan pengasuh tentang kondisi kesehatan dan masalah spesifik yang terkait dengan kecacatan akan mempengaruhi cara mengasuh. Jika pengasuh tidak memiliki pengetahuan tentang posisi yang benar untuk memberi makan anak dengan cerebral palsy, kejang otot dapat terjadi menyebabkan komplikasi dalam proses makan sehingga asupan makanan tidak cukup untuk anak. Pengetahuan tentang kondisi fisik anak dan sikap pengasuh dalam memberikan makan juga sangat penting bagi pengasuh. Anak dengan cerebral palsy mungkin perlu waktu lama untuk diberi makan disebabkan kondisi fisik anak, sehingga ibu mungkin kurang bersedia meluangkan waktu untuk mereka. Bentuk makanan juga menjadi faktor yang penting dalam daya kemampuan daya terima makan anak. ${ }^{20}$

Sebanyak $25-45 \%$ pada anak normal mengalami kesulitan makan. Namun pada anak dengan gangguan neorologis hingga $80 \%$ mengalami kesulitan makan. Kesulitan makan mempengaruhi asupan gizi sehingga mengganggu pertumbuhan anak. ${ }^{21}$

Penelitian Andrew dan Sullivan (2010), tentang masalah pemberian makanan pada 440 anak cerebral palsy adalah pemberian bantuan saat makan (89\%), tersedak dengan makanan $(56 \%)$, waktu makan lebih dari 3 jam per hari $(28 \%)$, sembelit $(26 \%)$ dan sering muntah (22\%). Namun di lain pihak, sebanyak lima puluh persen pengasuh stres saat memberikan makan, hampir dua per tiga pengasuh tidak melakukan pemantauan terhadap asupan dan status gizi anak. Asupan gizi sangat mempengaruhi status gizi pada anak cerebral palsy. Status gizi yang buruk dapat berdampak pada cedera otak pada anak cerebral palsy. Peningkatan status gizi memiliki dapak positif pada keterampilan anak cerebral palsy. ${ }^{10}$

\section{Hubungan Pengetahuan Pengasuh tentang Posisi Pemberian Makan dengan Asupan Protein}

Berdasarkan analisis penelitian didapatkan bahwa tidak terdapat hubungan yang signifikan antara pengetahuan pengasuh tentang posisi pemberian makan dengan asupan protein pada anak cerebral palsy di YPAC Malang dengan nilai $p$ sebesar $0,994(p>0,05)$.

Pertumbuhan dan perkembangan anak yang memiliki gangguan neurologis seperti cerebral palsy tidak hanya dipengaruhi oleh asupan nutrisi tetapi masalah fisik pada anak. Gangguan fisik anak dapat menyebabkan kekurangan asupan gizi. Asupan gizi mempengaruhi status gizi yang memiliki efek yang lebih kuat pada pertumbuhan dan perkembangan anak cerebral palsy. ${ }^{22}$

Salah satu asupan gizi untuk pertumbuhan dan perkembangan adalah protein. Asupan protein yang sangat penting untuk memperbaiki jaringan, pertumbuhan dan perkembangan anak. Saat ini tidak ada bukti yang menunjukkan perbedaan kebutuhan protein pada anak atau remaja cerebral palsy dengan anak pada umumnya sehingga rekomendasi asupan protein pada cerebral palsy bisa digunakan. ${ }^{23}$

Gangguan medis yang terjadi pada anak dengan gangguan neurologis dapat mempengaruhi proses makan. Masalah tersebut dapat mengganggu proses pembelajaran makan yang tepat untuk perkembangannya. ${ }^{24}$ Pemberian makan secara oral atau enteral bagi pengasuh harusnya memiliki pengetahuan tentang posisi pemberian makan, modifikasi, jenis makanan, prilaku pengasuh, tingkat stres pengasuh. ${ }^{23}$

\section{Keterbatasan Penelitian}

Masalah pemberian makan dipengaruhi oleh beberapa faktor yaitu posisi pemberian makan, stres pengasuh, lamanya waktu pemberian makan, jenis makanan, sikap dan dukungan keluarga, daya terima anak terhadap makanan, kemampuan motorik anak seperti menggigit, mengunyah serta menelan serta tingkat keparahan dari neurologis anak.

Jumlah pengasuh di Asrama YPAC Malang hanya ada 4 pengasuh saja sehingga jumlah anak disesuaikan dengan jumlah pengasuh. Kondisi ini menyebabkan sampel penelitian menjadi berkurang dan pengasuh anak cerebral palsy yang tinggal bersama keluarga ada yang tidak ikut berpartisipasi dalam penelitian karena jadwal pekerjaan yang padat. 


\section{Kesimpulan}

Tingkat pengetahuan pengasuh pada anak cerebral palsy di YPAC Malang dikategorikan baik. Rerata asupan energi dan protein lebih rendah daripada rerata kebutuhan energi dan protein berdasarkan Angka Kecukupan Gizi (AKG). Sebagian besar anak memiliki asupan energi dan protein kategori defisit berat dan defisit ringan dan tidak terdapat hubungan antara pengetahuan pengasuh tentang posisi pemberian makan dengan asupan energi maupun dengan asupan protein.

\section{Saran}

1. Penelitian dilakukan pada anak cerebral palsy yang tinggal bersama keluarganya sehingga jumlah pengasuh akan sesuai dengan jumlah anak cerebral palsy.

2. Ada penelitian lebih lanjut tentang posisi pemberian makan dengan asupan energi dan protein dengan desain penelitian yang berbeda.

\section{Daftar Pustaka}

1. Sugiarto F. Asupan dan Status Gizi Anak Palsy Cerebralis. Karya Tulis IImiah. Tidak Diterbitkan. Semarang: Fakultas Kedokteran Universitas Diponogoro. 2012.

2. Stanley FJ, Blair E and Alberman E. Cerebral Palsies: Epidemiology and Causal Pathways. Clinics in Developmental Medicine No 151. London: MacKeithPress. 2000.

3. Agency for Healthcare Research and Quality (AHRQ). Interventions for Feeding and Nutrition in Cerebral Palsy. 2013.

4. Wedati S. Model Intervensi Rehabilitatif Untuk Meningkatkan Kemandirian Melakukan Aktifitas Kehidupan Sehari-hari Anak Cerebral Palsy. Disertasi. Bandung: Universitas Pendidikan Indonesia. 2010.

5. Joashi A. Understanding and Managing Feeding Difficulties in Disabled Children. Paediatrics and Child Health. Harcourt Publishers Ltd. 2001.
6. Fung EB, Fang LS, Stallings VA, Conaway M, Liptak G, Henderson RC, et al. Feeding Dysfuction is Associated with Poor Growth and Health Status in Children with Cerebral Palsy. J Am Diet Assoc. 2002; 102:361368,373

7. Karande S, Patil S, Kulkarni M. Impact of an Educational Program on Parenteral Knowledge of Cerebral Palsy. Indian J Pediatri. 2008; 75(9):901-906.

8. Verall TC, Berenbaum S, Chad KE, Nanson JL, Zello GA. Children with Cerebral Palsy: Caregivers' Nutrition Knowledge, Attitudes and Beliefs. Canadian Journal of Dietetic Practice and Research. 2000; 61(3):128.

9. Herliana I. Pengalaman Keluarga dalam Merawat Anak Cerebral Palsy di Kabupaten Garut: Studi Fenomenologi. Tesis. Jakarta: Universitas Indonesia. 2011.

10. Andrew JM, Sullivan BP. Feeding Difficulties in Disabled Children. Proc Paediatric and Child Health. 2010; 20(7):321-326.

11. Hettiarachchi S, Kitnasamy G. Effect of an Experiential Dysphagia Workshop on Caregivers' Knowledge, Confidence, Anxiety and Behaviour during Mealtimes. Formerly Asia Pacific Disability Rehabilitation Journal. 2013; 24(3):7597.doi 10.5463/DCID.v24i3.73.

12. Siktberg LL, Bantz DL. Management of Children With Swallowing Disorders. J Pediatr Health Care. 1999; 13(5):223-9.

13. Kuperminc MN, Gottrand F, Fang LS, Arvedson J, Bell K, Craig GM, et al. Nutritional Management of Children with Cerebral Palsy: A Practical Guide. European Journal of Clinical Nutrition. 2013; 67:S21-S23. doi:10.1038/ejcn.2013.227.

14. Ahmed S, Badr EDS, Shenuda M, Mohamed A. Home Care Offered by Family Caregivers to Preschool Children, Suffering from Hemiplegic Cerebral Palsy. Journal of Biology, Agriculture and Healthcare. 2015; 5(4). 
15. Afifi A. Needs and Problems of Parents Caring for their Cerebral Palsy Child. Thesis. Faculty of Nursing, Community Health Nursing, Ain Shams University. 2006. P 1-7, 43,63,64,112-130.

16. Sangermano M, D'Aniello $R$, Massa $G$, Albano $R$, Pisano $P$, Budetta $M$, et al. Nutritional Problems in Children with Neuromotor Disabilities: an Italian Case Series. Ital J Pediatr. 2014; 40: 61.

17. Aggarwal S, Chadha R, Pathak R. Nutritional Status and Growth in Children with Cerebral Palsy: A Review. International Journal of Medical Science and Public Health. 2015; 4(6).

18. Penagini $F$, Mameli $C$, Fabiano V, Brunetti D, DililloD, Vincenzo ZG. Dietary Intakes and Nutritional Issues in Neurologically Impaired Children. Nutrients. 2015; 7:9400-9415. doi:10.3390/nu7115469.

19. Xavier L, Minolin M, Gowri PM. Effectiveness of Selected Feeding Techniques on Knowledge and Practice among Caregivers of Cerebral palsy
Children at Anbu Illam, Vellore. International Journal of Science and Research. 2013; 4(9).

20. The United Nations Children's Fund (UNICEF). Background Note for the Global Partnership on Children with Disabilities. Inclusive Nutrition for Children and Mothers with Disabilities. 2012.

21. Stanislavskaia J. Behavioral Feeding Problems of Normally Developing Children Under 4 Years of Age. Thesis. The University of Western Ontario. 2014.

22. Grammatikopoulou MG, Daskalou E, Tsigga M. Diet, Feeding Practices, and Anthropometry of Children and Adolescents with Cerebral Palsy and Their Siblings. Nutrition. 2009; 25:620-6.

23. Bell KL, Fang LS. Nutritional Management of Children with Cerebral Palsy. European Journal of Clinical Nutrition. 2013; 67:S13S16. doi:10.1038/ejcn. 2013.225.

24. NHS Trust. Eating Difficulties in Children and Young People with Disabilities. London: West London Mental Health.2014. 